\title{
Teacher Knowledge to Overcome Student Errors in Pythagorean Theorem Proof : A Study Based on Didactic Mathematical Knowledge Framework
}

\author{
Rudi $^{1}$, Didi Suryadi ${ }^{2}$, Rizky Rozjanuardi ${ }^{3}$ \\ \{rudi.math@upi.edu', didisuryadi1@gmail.com ${ }^{2}$, rizky@upi.edu ${ }^{3}$ \} \\ School of Post Graduate Studies, Mathematics Education, Universitas Pendidikan Indonesia, Agency \\ of Education Quality Assurance South Sulawesi Province, Indonesia ${ }^{1}$, Department of Mathematics \\ Education Universitas Pendidikan Indonesia, Bandung, Indonesia ${ }^{2,3}$
}

\begin{abstract}
Teachers' ability in overcoming to student errors is significantly affected by teachers' knowledge. Discussion and studies related to what knowledge teachers should possess have resulted in a theoretical framework. This article aims at describing teacher knowledge to responding student errors in Pythagorean Theorem proof using didactic mathematical knowledge approach. This research applies qualitative design. Five junior high school mathematics teachers in Indonesia participate in this study. Data were collected using written tests on teachers' competence and structured interview. Based on the analysis towards participants' responses, it can be concluded that teacher knowledge to overcome on student errors in Pythagoren Theorem proof is significantly affected by other knowledge components.
\end{abstract}

Keywords: Didactic mathematical knowledge, Pythagorean theorem proof, Student errors, Teacher knowledge

\section{Introduction}

During the process of achieving student competences in mathematics instruction, some students still face several problematic issues. One of those problems is student errors [1],[2]. Teachers need to be aware of the causes of student errors and take preventive action to enable an efficient learning environment to happen [3]. Identifying and overcoming student errors helps teachers to understand students' backgrounds and perceptions on academic subjects and shape their learning methods [4]. Analysis of student learning obstacles will improve teachers' faith and knowledge about students [5]. Teachers' experience in dealing with student errors is contributive to enrich teachers' competence and knowledge. Therefore, teachers' ability in responding to student errors is significantly affected by teachers' knowledge of student errors.

Brodie [6] elaborates on the use of student (learner) errors as a basis in teacher professional development through community. In his research, Brodie explains three phases of teacher thinking process namely process of identifying student (learner) errors, interpreting student (learner) errors, and developing teacher knowledge. Discussion and studies related to what knowledge teachers have resulted in theoretical framework as a basis in determining how teachers are trained, how teachers implement what they get in the training in their classroom practices, and how to formulate research problems [7]. 
Shulman [8] proposes a theoretical framework that views knowledge in integrated and solid manner. The theoretical framework is later known as Pedagogical Content Knowledge (PCK). Ball, Thames, and Phelps [9] identify a number of descriptions on teacher tasks during mathematics teaching and learning process. Based on the elaboration of those tasks, Ball et al. come up with an idea regarding "mathematical knowledge for teaching" (MKT) as a special knowledge needed by a teacher to teach mathematics.

Studies on teacher knowledge especially in geometry have been carried out by Chinnappan, White, \& Trenholm [10], Herbst \& Kosko [11], Kuzniak, \& Rauscher [12], Chinnappan, \& Lawson [13], and Jones, K. [14]. In more special cases, investigation on teacher knowledge and competence about student errors in geometry has been accomplished by Zuya [15], Zuya \& Kwalat [16], and Al-Khateeb [17]. Much of this research applies theoretical framework of mathematical knowledge for teaching developed by Ball et al. [9].

According to Gordino [18], the model of mathematical knowledge used in instructional model which progresses so far contains categories that are too general and not interconnected. It would have provided more benefits if the knowledge model enables us to do a more detail analysis of each type of knowledge to ensure more effectiveness in its implementation in mathematics learning. Based on this idea, Godino, Batanero, \& Font [19] propose a category system to analyze the knowledge model of mathematics teachers called "Didactic Mathematical Knowledge (DMK)".

According to Pino-Fan, Godino, \& Font [20], the two sub-categories which include DMK mathematical dimension is the reinterpretation of common content knowledge [21] and knowledge horizon [9], each. According to these writers, this interpretation is based on the need to accomplish the knowledge that mathematics teachers should master related to certain topics taught in several classes at certain schools.

DMK didactic dimension considers six sub-categories [20]: 1) Epistemic aspect including specific knowledge on mathematical dimension, 2) cognitive aspect including knowledge on students' cognitive aspect, 3) behavioral aspect covering knowledge on students' affective, emotional, and behavioral aspect, 4) interactional aspect covering knowledge needed by teachers to properly manage the students on certain mathematical topics by considering interaction as the basic component in the teaching and learning process, 5) learning media aspect covering knowledge that teachers need to utilize resources and facilities in managing the learning process, 6) environmental aspect covering knowledge on curricular, contextual, socialpolitical, and economic aspects which affect student learning management.

Geometry proof is one of the material that is considered difficult by students [22]. In the junior high school mathematics curriculum applicable in Indonesia, the proof of the Pythagorean theorem is one of the basic competencies that contains a proof of geometry [23]. This is what underlies this research takes the topic of proof of the Pythagorean theorem.

Notwithstanding a number of studies addressing teacher knowledge, those which examine teacher knowledge, especially in geometry. However, the study of teacher knowledge in overcoming student difficulties in geometry proof using didactic mathematical knowledge framework are still quite a few. Thus, this research will describe teacher knowledge on student errors in Pythagorean theorem proof using a didactic mathematical knowledge framework. The research question is how is teacher knowledge on student difficulties described within didactic mathematical knowledge framework? 


\section{Methodology}

The phenomenon being examined and researched in this study is teacher knowledge to overcome student errors in Pythagorean theorem proof. In revealing meaning or fact related to phenomenon of teacher knowledge on student errors, the researchers will accomplish two sets of activities. The first one is testing teacher knowledge on student errors and the second one is conducting an interview to verify teachers' answers on the written test. Next, the result of written tests and interviews with teachers are analyzed to yield a description of teacher knowledge to overcome student errors. The description of teacher knowledge to overcome student difficulties is obtained from written tests and interviews using didactic mathematical knowledge framework which is based on hermeneutics philosophy.

The research participants are selected purposively and are based on planning [24]. Five mathematics teachers in junior high schools in Indonesia namely IS, EN, DD, FS, and YK. Those teachers teach mathematics in grade VII, VIII, and IX. The instrument of this research that tests teacher competence to overcome student errors in proving Pythagorean Theorem is presented below. How do you calculate the ABCD trapezoid area? follow Figure 1.

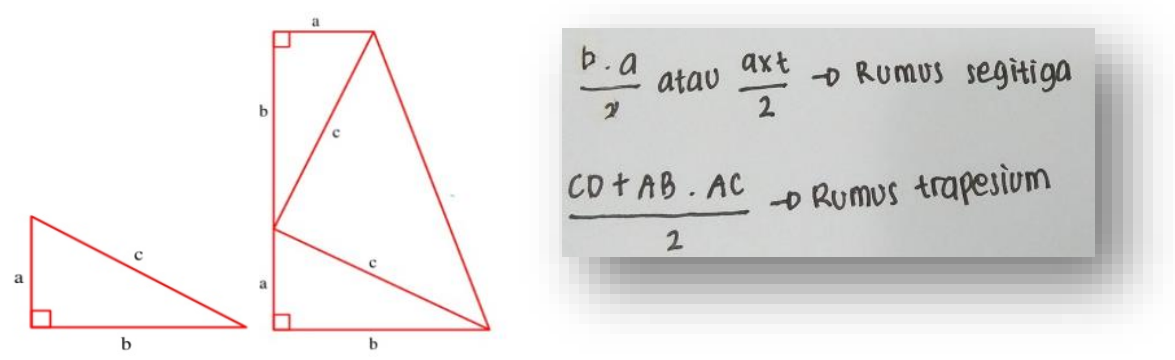

Fig. 1. Student Answer.

By implementing the formulation to calculate the rectangle and trapezoid area, prove that on the right triangle above, it applies $c^{2}=a^{2}+b^{2}$. Based on the question and student's answer above, teachers ask to answer the 12 questions. Data analysis in qualitative research is done since the beginning and during the research is being carried out. Data analysis of teacher knowledge on student learning difficulties is accomplished after teachers complete the written test and interview. Data on teachers' work and interviews are analyzed using theoretical framework of didactic mathematical knowledge so that it results in a description of teacher knowledge to overcome student errors within the topic of geometry proof.

\section{Findings and Discussion}

This section describes teacher knowledge to overcome student errors based on didactic mathematical knowledge framework. The components of teacher knowledge cover mathematical and didactic knowledge namely aspects of epistemic, cognitive, ecological, interactional, affective, and media.

\subsection{Mathematical Knowledge To Overcoming Student Errors}


A brief description of mathematical knowledge of five teachers identified as EN, IS, FS, $\mathrm{DD}$, and YK is presented as follows:

In responding to teacher knowledge to overcoming student errors in proving Pythagorean theorem, EN left the answer column blank. During the interview, they said that the questions were too complicated; they have never taught about it. They could accomplish proving only on questions related to the topic that they have taught to students. Meanwhile, they only use learning materials that are available in the textbook. Is answered the question in the following Figure 2. Meanwhile, DD responded to the question by writing this in Figure 3. Figure 4 below is how FS responded to the question and YK answered in the following Figure 5.

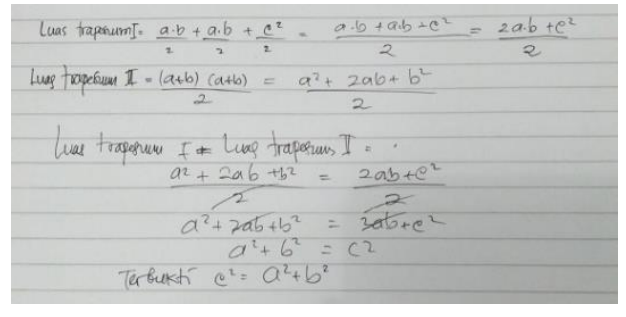

Fig. 2. Is Answered.

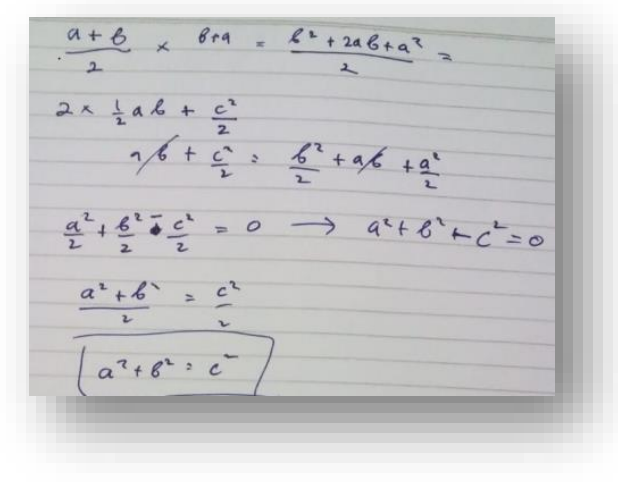

Fig. 4. FS Responded.

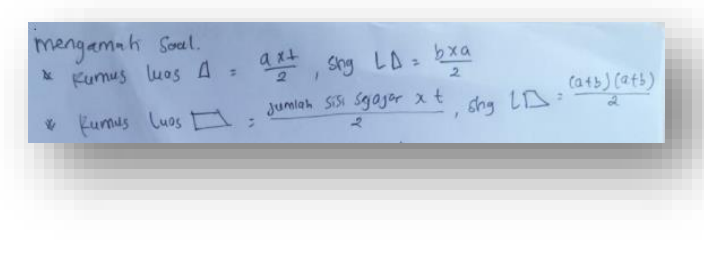

Fig. 3. DD Responded.

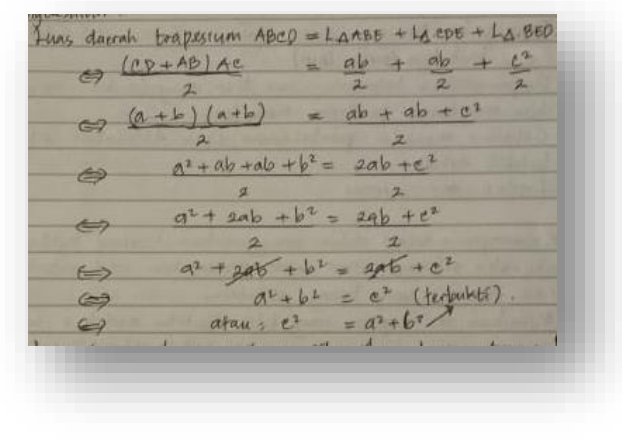

Fig. 5. YK Answered.

The answers from the five participants show that EN and DD found difficulties in solving the problems while the answers from IS, FS, and YK signified that the participants were able to solve the problem and accurately prove Pythagorean theorem. It can be concluded that three teacher participants possess good mathematical knowledge to overcome student errors in proving Pythagorean theorem.

\subsection{Didactical Knowledge to Overcome in Student Errors}


Teacher didactic knowledge on the epistemic aspect is represented in the question "what competence do teachers want to measure through the question?" (part a) and "what knowledge or concept plays a role to solve the question?" (part b).

The competence measured through the question is the ability to identify the Pythagorean theorem using the formulation of triangle and trapezoid area. Meanwhile, in part e, IS wrote, algebra (addition and powers of numbers), geometry (addition of two lines and area of twodimensional figure). EN responded to question part as follows: Student mastery on Pythagorean theorem means that they can differentiate each side and calculate the area.

Referring to the participants' responses and answers on questions part a and e, it can be concluded that IS and EK possess epistemic knowledge to overcome student errors in proving Pythagorean theorem. Meanwhile, EN, DD, and FS possess limited epistemic knowledge to overcome student errors in proving Pythagorean theorem.

Teacher didactic knowledge on cognitive aspect is measured through the instrument with the following questions: question part c 'based on students' answers, what is students' main difficulty in solving the problem in the question?", question part d, "to your opinion, why do students find difficulties in solving the problem?", and question part g, "how is the flow of students' thinking to provide accurate answer to the question?".

Referring to the participants' answers to cognitive knowledge-related questions in overcoming student errors, a conclusion can be drawn. IS, FS, and EK, despite the differences in identifying student difficulties and the respective causes, they possess similar knowledge on students' thinking flow in solving the problem. On the other hand, EF and DD still find difficulties in identifying the flow of students' thinking in solving problem.

Teacher didactic knowledge on the interactional aspect is measured through the instrument, on part $\mathrm{h}$ to be precise, which is formulated as "what design of learning situation/activity will you apply to overcome student difficulties based on the respective students' flow of thinking?". The five participants gave various responses to the question. The elaboration is presented below.

Based on participants' answers to question $h$, it can be concluded that IS and YK elaborate the design of learning situation and strategy based on students' thinking flow whereas EN, DD, and FS do not elaborate the situation/strategy design based on the flow of students' thinking in solving the problem.

Teacher didactic knowledge on the ecological aspect is measured through the instrument on part $\mathrm{f}$, stated as "Is the question above appropriate for grade VIII junior high school students? Explain why". The five participants generate various responses to the question. The following is the elaboration of participants' answers to the question part $\mathrm{f}$.

Based on participants' answers, only YK thinks that the question is appropriate to be given to grade VIII students considering that pre-requisite knowledge has been fulfilled in the previous learning phase. While for DD, notwithstanding his thought of considering the question appropriate, he comes up with a different reason. IS, EN, and FS state that the question is not suitable for grade VIII students. IS and FS think that there are still many students who have problematic issues with pre-requisite information although they have learned it before. Thus, in spite of having learnt the topic, difficulties in solving the problem still exist.

Teacher didactic knowledge on the affective aspect is measured through the instrument on part I, j, and k comprising the questions of "what steps will be accomplished in the classroom to motivate students to solve the question?" (part i), "what strategy will you employ to integrate social attitude during the learning process so that students can solve the problem?" (part j), and "what strategy will you apply to integrate spiritual attitude during learning process so that students can deal with the question?" (part k). 
Based on participants' responses above, it shows that participants in helping students to deal with their difficulties have not been able yet to integrate attitude aspect into learning materials. The strategy offered is still loose, not interrelated, and not integrated yet with learning materials.

Teacher didactic knowledge on media aspect is measured through the instrument on part 1 stating what media do you utilize to overcome the respective student difficulties?

Responses from IS, EN, and FS show the use of media to overcome student errors by utilizing teaching aid. DD, YK, and FS emphasized the use of information and communication technology-based media. However, the five participants have not yet elaborated on the technical aspect in utilizing the media within the context of student learning difficulties regarding the topic of proving Pythagorean theorem.

Referring to the responses from EN and DD, there is an initial portrayal that the two participants find difficulties in solving the problem. It indicates that their mathematical knowledge needs improvement. Research findings also signify that EN and DD still find it complicated in identifying student difficulties and the causes, and in describing the flow of students' thinking in solving the problem. EN's and DD's complexity also appears when they have to elaborate relevant learning design/ strategy, integration of attitude value, and determining media which are appropriate with student learning difficulties. Based on didactic mathematical knowledge framework [20], EN and DD possess limited mathematical knowledge and didactic knowledge on cognitive, epistemic, interactional, affective, ecological, and media aspects.

This finding supports the finding of research conducted by Mdu Ndlovu and Andile Mji [24] stating that teachers find it complicated in determining the strategy in dealing with student difficulties to prove Pythagorean theorem. Teachers discover complexities in identifying student misunderstanding and predicting the flow of students' thinking [15]. Habila Elisha Zuya and Simon Kevin Kwalat [16] mention that teachers do not have the competence to identify knowledge that students do not possess yet which makes it difficult for them to solve problems related to angles in parallel lines. Besides, teachers have limitations in giving suggestions regarding strategies to cope with student difficulties. A research accomplished by Al-Khateeb [17] shows that junior high school students in Saudi Arabia experience misconception in geometric learning like parallelogram, trapezoid, rhombus, etc. Besides, this research reveals that mathematics teachers are lack of awareness in identifying the students' mistakes.

This finding is supported by Sorto, Shalem, \& Spaire [25] who locate procedural and conceptual understanding of accurate answers as one of basic steps for teachers to overcome student learning errors. Therefore, teacher knowledge and competence really depend on mathematical knowledge that they possess [26]. Thus, it is expected that it can improve the quality of mathematics learning [27]. In the end, teacher mathematical knowledge plays a significant role to improve students' learning outcomes [28].

The finding of this research also portrays that teachers who possess the knowledge to analyze the causes of student difficulties do not find it complicated in designing learning materials. This highlights the importance of teachers' understanding of students learning obstacles as a basis to develop learning materials. This finding goes along with Suryadi [29] who underlines didactic design development based on analysis of student learning obstacles and trajectory. 


\section{Conclussion}

Research findings show that two participants cannot accurately answer the questions in the instrument which measures teachers' mathematical knowledge needed to overcome student errors. Another finding indicates that those teachers who do not possess mathematical knowledge in dealing with student errors are also not completed with good didactic knowledge, especially on cognitive, epistemic, ecological, and interactional aspects.

Based on the analysis towards participants' responses, it can be concluded that teacher knowledge to overcome on student errors in Pythagoren Theorem proof is significantly affected by other knowledge components. Therefore, attachment and integration among teacher knowledge components are necessary. Teacher knowledge is a unity which is inseparable from other teacher knowledge components.

Attachment and integration of teacher knowledge components are expected to serve as a main consideration in developing a design of teacher reflective practice as a model of mathematics teacher professional development [50]. Therefore, it is necessary to change the paradigm from professional development to professional learning of mathematics teachers which is highly supported by a theoretical framework which views teacher knowledge in a solid and integrated manner.

Acknowledgments. Gratitude and appreciation are highly addressed to Lembaga Pengelola Dana Pendidikan (LPDP), Ministry of Finance as the main sponsor of this research.

\section{References}

[1] Hendrik, R.: Students' errors in the mathematical learning process: a survey. For the learning of Mathematics 1.1. pp. 16-20 (1980)

[2] De Bock, D., Van Dooren, W., Janssens, D., \& Verschaffel, L.: Improper use of linear reasoning: An in-depth study of the nature and the irresistibility of secondary school students' errors. Educational studies in mathematics 50.3. pp. 311-334 (2002)

[3] Bobby, O.: Students' misconceptions in mathematics: Analysis of remedies and what research says. (2015)

[4] Murphy, P. K., Alexander, P. A., Greene, J. A., \& Hennessey, M. N.: Examining epistemic frames in conceptual change research: Implications for learning and instruction. Asia Pacific Education Review 13.3. pp. 475-486 (2012)

[5] Sbaragli, S., Arrigo, G., D'Amore, B., Fandiño Pinilla, M. I., Frapolli, A., Frigerio, D., \& Villa, O.: Epistemological and Didactic Obstacles: the influence of teachers' beliefs on the conceptual education of students. Mediterranean journal for research in mathematics education 10. Pp. 61-102 (2011)

[6] Karin, B.: Learning about learner errors in professional learning communities. Educational studies in mathematics 85.2. pp. 221-239 (2014) [9] Murphy, P. Karen, et al.: Examining epistemic frames in conceptual change research: Implications for learning and instruction. Asia Pacific Education Review 13.3. pp. 475-486 (2012)

[7] Robin, B.R.: Digital storytelling: A powerful technology tool for the 21 st century classroom. Theory into practice 47.3. pp. 220-228 (2008)

[8] Shulman, L.S.: Those who understand: Knowledge growth in teaching. Educational researcher 15.2. pp. 4-14 (1986)

[9] Ball, L.D., Thames, M.H. and Phelps, G.: Content knowledge for teaching: What makes it special?. Journal of teacher education 59.5. pp. 389-407 (2008) 
[10] Mohan, C., White, B. and Trenholm, S.: Symbiosis Between Subject Matter and Pedagogical Knowledge in Geometry. International Perspectives on the Teaching and Learning of Geometry in Secondary Schools. Springer, Cham, pp. 145-161 (2018)

[11] Patricio, H and Kosko, K.: Mathematical Knowledge for Teaching High School Geometry. North American Chapter of the International Group for the Psychology of Mathematics Education (2012)

[12] Alain, K. and Rauscher, J.C.: How do teachers' approaches to geometric work relate to geometry students' learning difficulties?. Educational studies in Mathematics 77.1. pp. 129-147 (2011)

[13] Mohan, C. and Lawson, M.J.: A framework for analysis of teachers' geometric content knowledge and geometric knowledge for teaching. Journal of Mathematics Teacher Education 8.3. pp. 197-221 (2005)

[15] Keith, J.: Teacher knowledge and professional development in geometry. Proceedings of the British society for research into learning mathematics 20.3. pp. 109-114 (2000)

[15] Zuya and Habila, E.: Mathematics teachers' ability to investigate students' thinking processes about some algebraic concepts. Journal of Education and Practice 5.25. pp. 117-122 (2014)

[16] Zuya, Elisha, H. and Kwalat, S.K.: Teacher's Knowledge of Students about Geometry (2015)

[17] Al-Khateeb and Ahmad, M.: The Extent of Mathematics Teacher's Awareness of Their Students' Misconceptions in Learning Geometrical Concepts in the Intermediate Education Stage (2016)

[18] Godino, J.D.: Categorías de análisis de los conocimientos del profesor de matemáticas (2009)

[19] Godino, J.D., Carmen, B. and Vicenç, F.: Un enfoque ontosemiótico del conocimiento y la instrucción matemática. ZDM. The International Journal on Mathematics Education 39. Pp. 127-135 (2007)

[20] Fan, P., Luis R., Assis, A. and Gordillo, W.F.C.: Towards a methodology for the characterization of teachers' Didactic-Mathematical knowledge (2015)

[21] Özerem, Ayşen.: Misconceptions in geometry and suggested solutions for seventh grade students." Procedia-Social and Behavioral Sciences 55. Pp. 720-729 (2012)

[22] Kebudayaan, Menteri Pendidikan. Peraturan Menteri Pendidikan dan Kebudayaan Republik Indonesia Nomor 26 Tentang Kompetensi Inti dan Kompetensi Dasar Pelajaran pada Pendidikan Dasar dan Menengah. Jakarta: Depdikbud (2016)

[23] Cresswell, J.W.: Penelitian Kualitatif \& Desain Riset (Terjemahan). Yogyakarta, Pustaka Pelajar. (2014)

[24] Ndlovu, Mdutshekelwa, and Mji, A.: Pedagogical implications of students' misconceptions about deductive geometric proof. Acta Academica 44.3.pp. 175-205 (2012)

[25] Sorto, M. Alejandra, Shale, Y. and Sapire, I.: Teachers' explanations of learners' errors in standardised mathematics assessments. Pythagoras 35.1. pp. 1-11 (2014)

[26] Baumert, J., Kunter, M., Blum, W., Brunner, M., Voss, T., Jordan, A \& Tsai, Y. M.: Teachers' mathematical knowledge, cognitive activation in the classroom, and student progress. American educational research journal 47.1. pp. 133-180 (2010)

[27] Ball, Deborah Loewenberg.: Research on Teaching Mathematics: Making Subject Matter Knowledge Part of the Equation (1988)

[28] Hill, H.C., Brian R. and Ball, D.L.: Effects of teachers' mathematical knowledge for teaching on student achievement. American educational research journal 42.2. pp. 371-406 (2005)

[29] Suryadi, D.: Didactical design research (DDR) to improve the teaching of mathematics. Far East Journal of Mathematical Education 10.1. pp. 91-107 (2013) 